OPEN ACCESS

Edited by:

Jacques Epelbaum

Institut National de la Santé et de la Recherche Médicale, France

Reviewed by:

James A. Carr

Texas Tech University, USA

Jean-Louis Guillou,

University of Bordeaux 1, France

*Correspondence:

Andreas Stenge

andreas.stenge/@charite.de

Specialty section:

This article was submitted to

Neuroendocrine Science

a section of the journal

Frontiers in Neuroscience

Received: 01 February 2017 Accepted: 06 April 2017

Published: 25 April 2017

Citation:

Stengel A and Taché YF (2017)

Activation of Brain Somatostatin

Signaling Suppresses CRF

Receptor-Mediated Stress Response.

Front. Neurosci. 11:231.

doi: 10.3389/fnins.2017.00231

\section{Activation of Brain Somatostatin Signaling Suppresses CRF Receptor-Mediated Stress Response}

\author{
Andreas Stengel ${ }^{1 *}$ and Yvette F. Taché2,3 \\ ${ }^{1}$ Division of Psychosomatic Medicine, Charité Center for Internal Medicine and Dermatology, Charité-Universitätsmedizin \\ Berlin, Berlin, Germany, ${ }^{2}$ Vatche and Tamar Manoukian Digestive Diseases Division, CURE Digestive Diseases Research \\ Center, G Oppenheimer Center for Neurobiology of Stress and Resilience, Department of Medicine, University of California, \\ Los Angeles, Los Angeles, CA, USA, ${ }^{3}$ VA Greater Los Angeles Health Care System, Los Angeles, CA, USA
}

Corticotropin-releasing factor (CRF) is the hallmark brain peptide triggering the response to stress and mediates -in addition to the stimulation of the hypothalamus-pituitary-adrenal (HPA) axis-other hormonal, behavioral, autonomic and visceral components. Earlier reports indicate that somatostatin-28 injected intracerebroventricularly counteracts the acute stress-induced ACTH and catecholamine release. Mounting evidence now supports that activation of brain somatostatin signaling exerts a broader anti-stress effect by blunting the endocrine, autonomic, behavioral (with a focus on food intake) and visceral gastrointestinal motor responses through the involvement of distinct somatostatin receptor subtypes.

Keywords: brain-gut axis, food intake, gastrointestinal functions, HPA, hypothalamus, stress

\section{INTRODUCTION}

The past years have witnessed major advances in our understanding of the underlying mechanisms involved in the bodily response to stress (Chrousos and Zoumakis, 2017). Namely, the corticotropin-releasing factor (CRF) systems in the brain play a major role in coordinating an array of stress-related behavioral, endocrine, autonomic and visceral changes as well as the stress recovery through activation of distinct CRF receptor subtypes (Bale and Vale, 2004; Taché and Million, 2015; Henckens et al., 2016). This was established by monitoring alterations of CRF systems occurring during stress exposure in specific brain nuclei and the impact of pharmacological or targeted genetic manipulations of CRF ligands and/or receptors on the stress response (Suda et al., 2004; Chen et al., 2014; Rivier and Rivier, 2014; Taché and Million, 2015; Henckens et al., 2016). Simultaneously, other brain pathways are recruited by stress that exert stress-relieving effects (Bali et al., 2014). Among them, the activation of brain neuropeptide $Y_{1}$ and oxytocin receptors have been implicated in stress adaptation processes as recently reviewed (Zheng et al., 2010; Reichmann and Holzer, 2016). Earlier reports by Brown et al. showed that the injection of somatostatin- 28 into the lateral brain ventricle blocked acute stressors-induced rise of ACTH and epinephrine plasma levels in rats (Brown et al., 1984). The present review will summarize mounting evidence indicating that activation of brain somatostatin signaling at different brain sites exerts an anti-stress action that extends to several components of the stress response through distinct somatostatin receptor subtypes. 


\section{Brain Corticotropin Releasing Factor Signaling}

In 1950, Harris and colleagues reported that different stressors stimulate the release of adrenocorticotropic hormone (ACTH) via a yet unknown hypothalamic factor (de Groot and Harris, 1950; Harris, 1950). Five years later, Guillemin and coworkers purified a factor able to stimulate pituitary ACTH secretion using a large sample of bovine hypothalami (Guillemin and Rosenberg, 1955; Saffran et al., 1955). This factor was named CRF (Guillemin and Rosenberg, 1955; Saffran et al., 1955). However, it took another 26 years to identify and sequence the 41-amino acid peptide that plays a pivotal role in the stress-related pituitary release of ACTH and $\beta$-endorphin (Vale et al., 1981; Bale and Chen, 2012). Besides acting as a secretagogue of the hypothalamus-pituitary-adrenal (HPA) axis, CRF was subsequently implicated in stress-related alterations of autonomic (Yang et al., 2010; Bardgett et al., 2014), visceral (Taché and Million, 2015), behavioral (Bale and Vale, 2004), and also immune (Gravanis and Margioris, 2005) responses.

Following the characterization of CRF, additional structurally related members of the CRF peptide family were identified, namely urocortin 1 (Ucn 1, 40 amino acids, 45\% sequence homology with rat/human CRF) (Vaughan et al., 1995), Ucn 2 (39 amino acids, 34\% sequence homology with rat/human CRF) (Reyes et al., 2001) and Ucn 3 (38 amino acids, 26\% sequence homology with rat/human CRF) (Lewis et al., 2001). These peptides are encoded by distinct genes highly conserved across mammalian and non-mammalian species (Lovejoy and de Lannoy, 2013).

Mapping studies identified prominent CRF expression in the cerebral cortex, amygdala, hippocampus and the Barrington's nucleus in rodents (Wang et al., 2011). Likewise, urocortins display broad distribution although there is little overlap with that of CRF. Ucn 1 immunoreactivity is mainly expressed in the Edinger-Westphal nucleus (Bittencourt et al., 1999), while Ucn 2 mRNA (due to the lack of a specific antibody) has been detected in the supraoptic nucleus, the paraventricular and arcuate nucleus of the hypothalamus, the locus coeruleus, several cranial nerve motor nuclei and the ventral horn of the spinal cord (Reyes et al., 2001; Mano-Otagiri and Shibasaki, 2004). Lastly, Ucn 3 mRNA and peptide expression have been identified in the amygdala, lateral septum, ventromedial hypothalamus and paraventricular nucleus of the hypothalamus, basomedial nucleus of the stria terminalis, dorsal raphe nucleus and the area postrema (Lewis et al., 2001; Li et al., 2002; Mano-Otagiri and Shibasaki, 2004; Venihaki et al., 2004).

The various biological effects of CRF and Ucns are mediated by binding to and activating two distinct seven-transmembrane domain (TMD) G-protein-coupled receptor subtypes, $\mathrm{CRF}_{1}$ and/or $\mathrm{CRF}_{2}$ that belong to the $\mathrm{B} 1$ subfamily (Perrin and Vale, 1999). CRF ligands display distinct affinity to CRF receptors with CRF binding preferentially to $\mathrm{CRF}_{1}$ and with lesser affinity to $\mathrm{CRF}_{2}$ (Hillhouse and Grammatopoulos, 2006), while Ucn 1 displays equal high affinity to both $\mathrm{CRF}_{1}$ and $\mathrm{CRF}_{2}$ and $\mathrm{Ucn}$ 2 and 3 are selective $C_{R F}$ agonists (Grace et al., 2007). Both $\mathrm{CRF}$ receptors are encoded by distinct genes which exhibit diverse alternative pre-mRNA splicing patterns resulting in multiple variants derived from partial or total exon deletions or insertions (Grammatopoulos et al., 1999; Pisarchik and Slominski, 2001; Wu et al., 2007, 2011; Zmijewski and Slominski, 2010; Grammatopoulos, 2012; Yuan et al., 2012, 2016). With regard to the nine human $\mathrm{CRF}_{1}$ variants, $\mathrm{CRF}_{1 \mathrm{a}-\mathrm{i}}$, described, $\mathrm{CRF}_{1 \mathrm{a}}$ being the main wild type functional receptor while the other isoforms may modulate CRF signaling (Zmijewski and Slominski, 2010; Wu et al., 2011). For the $\mathrm{CRF}_{2}$, three functionally active splice variants, $\mathrm{CRF}_{2 \mathrm{a}-\mathrm{c}}$, have been described in humans (Hillhouse and Grammatopoulos, 2006).

In line with the widespread expression of CRF ligands, $\mathrm{CRF}_{1}$ and $\mathrm{CRF}_{2}$ are also widely distributed in the rodent brain (Van Pett et al., 2000; Justice et al., 2008). $\mathrm{CRF}_{1}$ is prominently expressed in the forebrain including the isocortex throughout cortical layers II-VI, hippocampal formation at the CA1 level, basal ganglia within the globus pallidus and striatum, sensory systems and the amygdala (Justice et al., 2008; Kuhne et al., 2012), while basal levels are low in the hypothalamus (Bonaz and Rivest, 1998) and spinal cord (Kuhne et al., 2012). Moreover, $\mathrm{CRF}_{1}$ was also detected in all segments of the mouse spinal cord throughout laminae II-V (Korosi et al., 2007). The $\mathrm{CRF}_{2}$ shows a wide distribution in the brain, most notably in the amygdala, lateral septum, supraoptic nucleus, ventromedial hypothalamus, dorsal raphe nuclei, area postrema, the nucleus of the solitary tract and the spinal cord (Bittencourt and Sawchenko, 2000; Korosi et al., 2007; Lukkes et al., 2011).

\section{Brain Somatostatin Signaling}

Somatostatin-14 was isolated in 1973 from ovine hypothalami and shown to inhibit growth hormone secretion in vitro (Brazeau et al., 1973). Seven years later, the N-terminally extended form, somatostatin-28, generated by differential posttranslational processing from a common precursor molecule, was identified (Pradayrol et al., 1980). The somatostatinergic system also encompasses cortistatin, an evolutionary-related peptide that shares high structural and functional similarity to somatostatin although derived from a distinct gene (de Lecea et al., 1996; Gahete et al., 2008). In the rat brain, the pre-pro-hormone gives rise to cortistatin-14 and -29, while in humans, it leads to a 17-amino acid peptide (Hannon et al., 2002a).

Besides the initially described expression site in the hypothalamus, somatostatin is widely distributed in the rodent brain with dense expression in the cortex, amygdala, limbic and sensory system, periaqueductal central gray and paraventricular, ventromedial and arcuate hypothalamic nuclei (Finley et al., 1981; Johansson et al., 1984; Moga and Gray, 1985; Viollet et al., 2008).

Somatostatin-14 and somatostatin-28 bind to five receptor subtypes $\left(s_{1-5}\right)$, all belonging to G-protein-coupled TMD receptors encoded by different non-allelic and intronless genes (Theodoropoulou and Stalla, 2013). Different functionally active isoforms have been described for the $s_{2} t_{2}$ and $\mathbf{s s t}_{5}$. The full length $s^{2} t_{2 a}$ and the truncated $s_{2} t_{2 b}$ differ only in the length and composition of their C-terminal domains (Cole and Schindler, 2000). The truncated sst $_{5}$ variants differ by their shorter C-terminal tails and display less than seven TMD which vary between species and have been named 
accordingly (rat sst ${ }_{5} \mathrm{TMD} 1$; mouse sst ${ }_{5} \mathrm{TMD} 1$, sst $_{5} \mathrm{TMD} 2$ and sst 5 TMD4; pig sst 5 TMD3 and sst ${ }_{5}$ TMD6; human sst ${ }_{5}$ TMD4 and sst 5 TMD5) (Duran-Prado et al., 2009, 2012; Cordoba-Chacon et al., 2010).

In line with the mapping of the ligand, the sst receptors are widely expressed in the rodent brain with the following regional pattern: all layers of the cerebral cortex $\left(\right.$ sst $_{1}$, sst $_{2 \mathrm{a} / \mathrm{b}}$, $\left.\mathrm{sst}_{3}, \mathrm{sst}_{4}\right)$, bed nucleus of the stria terminalis $\left(\mathrm{sst}_{1}, \mathrm{sst}_{2 \mathrm{a}, \mathrm{b}}, \mathrm{sst}_{4}\right)$, hippocampus (sst $\left.{ }_{1}, s s t_{2 a, b}, s s_{3}, s s t_{4}\right)$, basolateral amygdaloid nucleus ( $\left(\mathrm{st}_{1}, \mathrm{sst}_{2 \mathrm{a} / \mathrm{b}}, \mathrm{sst}_{3}, \mathrm{sst}_{4}\right.$ ), medial amygdaloid nucleus ( st $_{1}$, $\mathrm{sst}_{2}, \mathrm{sst}_{3}$ ), ventromedial hypothalamic nucleus ( $\mathrm{sst}_{1}, \mathrm{sst}_{2}, \mathrm{sst}_{3}$ ), dorsomedial hypothalamic nucleus ( $\mathrm{sst}_{1}, \mathrm{sst}_{3}$ ), paraventricular nucleus $\left(\mathrm{sst}_{2 \mathrm{a}}, \mathrm{sst}_{3}\right)$ and arcuate nucleus of the hypothalamus $\left(\right.$ sst $_{1}$, sst $\left._{2 \mathrm{a}}, \mathrm{sst}_{3}, \mathrm{sst}_{4}\right)$, substantia nigra $\left(\mathrm{sst}_{1}, \mathrm{sst}_{2 \mathrm{a} / \mathrm{b}}, \mathrm{sst}_{3}\right)$, dorsal raphe nucleus ( sst $\left._{1}, \mathrm{sst}_{2}, \mathrm{sst}_{3}\right)$, locus coeruleus ( $\left.\mathrm{sst}_{2}, \mathrm{sst}_{3}\right)$, granular layer of the cerebellum ( $\mathrm{sst}_{1}, \mathrm{sst}_{2 \mathrm{~b}}, \mathrm{sst}_{3}, \mathrm{sst}_{4}, \mathrm{sst}_{5}$ ), dorsal motor nucleus of the vagus nerve (sst ${ }_{2 \mathrm{a}, \mathrm{b}}, \mathrm{sst}_{4}, \mathrm{sst}_{5}$ ) and nucleus of the solitary tract $\left(\mathrm{sst}_{1}, \mathrm{sst}_{2}, \mathrm{sst}_{3}\right.$ ) (Schindler and Humphrey, 1999; Fehlmann et al., 2000; Schulz et al., 2000; Hannon et al., 2002b; Videau et al., 2003; Spary et al., 2008; Kumar, 2012). With regards to the truncated sst 5 variants, they show a distinct distribution with a high abundance of full length sst ${ }_{5}$ in mouse hypothalamus and cerebellum followed by sst ${ }_{5}$ TMD2 and sst ${ }_{5}$ TMD1, whereas sst 5 TMD4 is not detectable (Hannon et al., 2002b; CordobaChacon et al., 2010). By contrast, in the mouse cortex full length sst ${ }_{5}$ is absent, while all truncated variants are expressed (sst ${ }_{5}$ TMD2, sst ${ }_{5}$ TMD4, sst 5 TMD1) (Cordoba-Chacon et al., 2010) indicative of a prominent role of truncated sst ${ }_{5}$ variants in this brain area. The distinct expression pattern is important in the context of pharmacological characteristics of truncated variants. Indeed, in vitro studies showed that cells expressing the sst ${ }_{5}$ TMD2 mainly respond to cortistatin, whereas those expressing sst ${ }_{5}$ TMD4 4 were exclusively activated by somatostatin and those bearing the sst 5 TMD1 responded to both ligands (Cordoba-Chacon et al., 2010, 2011). It is to note that species differences exist since in humans, cortistatin activates sst ${ }_{5}$ TMD4, while somatostatin activates the sst 5 TMD5 (Duran-Prado et al., 2009; Cordoba-Chacon et al., 2011).

Somatostatin in the brain exerts a wide variety of physiological functions besides the initially described inhibitory effect on growth hormone release. Its actions include increased locomotor activity (Viollet et al., 2008), memory and learning (Vecsei and Widerlov, 1988; Gastambide et al., 2009), and sleep (Steiger, 2007; Xu et al., 2015), as well as changes in autonomic cardiovascular and gastric functions (e.g., sympatho-inhibitory effect with lowering of heart rate and blood pressure, stimulation of gastric secretion and transit) (Brown and Taché, 1981; Martinez et al., 2000; Bou Farah et al., 2016), immune functions (Gonzalez-Rey et al., 2015) and ingestive behaviors (e.g., increased feeding and drinking; Stengel et al., 2015). Of importance in relation with stress, injection of somatostatin into the brain influences emotional processes exerting anxiolytic and anti-depressant effects (Engin and Treit, 2009; Scheich et al., 2016). However, in contrast to other anxiolytics such as benzodiazepines, somatostatin exerts pro-cognitive effects under healthy (Liguz-Lecznar et al., 2016) and Alzheimer's disease conditions (Epelbaum et al., 2009).

\section{RESPONSE TO STRESS}

\section{Activation of CRF Signaling}

CRF expression is upregulated in the hypothalamus and the peptide released into the median eminence under conditions of stress leading to pituitary ACTH and subsequently adrenal glucocorticoid hormone release (cortisol in humans and corticosterone in rodents) (Turnbull and Rivier, 1997; Smith and Vale, 2006; Kageyama and Suda, 2009). Moreover, hypothalamic $\mathrm{CRF}_{1}$ receptors are also upregulated in rodents exposed to acute or chronic stress by a CRF feed-forward mechanism (Bonaz and Rivest, 1998; Imaki et al., 2001; Konishi et al., 2003; Wan et al., 2014; Eraslan et al., 2015). The use of selective CRF receptor subtype agonists and antagonists as well as transgenic animal models established the primary role of $\mathrm{CRF}_{1}$ receptor in driving the stress-related HPA, behavioral, autonomic and visceral responses (Turnbull and Rivier, 1997; Luckey et al., 2003b; Farrokhi et al., 2007; Kehne and Cain, 2010; Taché, 2015).

\section{Activation of Somatostatin Signaling}

Somatostatin signaling is also activated by different stressors. In particular, immobilization (Negro-Vilar and Saavedra, 1980; Arancibia et al., 2000), handling (Arancibia et al., 1984), maternal separation (Polkowska and Wankowska, 2010), hypoxia (Chen and Du, 2002), pain (Arancibia et al., 1984), and injection of endotoxin (Priego et al., 2005) increase hypothalamic somatostatin mRNA levels and peptide release. Somatostatin release also occurred in the dorsal dentate gyrus in rats subjected to immobilization (Arancibia et al., 2001). Moreover, rats exposed to an elevated plus maze displayed an activation of somatostatin positive neurons in the basolateral amygdala (Butler et al., 2012). The activation of somatostatin signaling under conditions of stress is not restricted to the ligand but also occurred at the receptor level. In the amygdala and anterior cingulate cortex, sst 2 mRNA was upregulated following acute exposure of rats to a potential predator (Nanda et al., 2008), a finding recently also observed in the medial habenula following chronic mild stress (Faron-Gorecka et al., 2016).

\section{SUPPRESSION OF THE CRF-MEDIATED STRESS RESPONSE BY ACTIVATION OF SOMATOSTATIN SIGNALING}

\section{Endocrine Response}

Initial reports by Brown et al. showed that intracerebroventricular (icv) injection of the pan-sst agonist, somatostatin-28 or the oligo-somatostatin agonist, desAA1,2,4,5,12,13-[D-Try $]$ somatostatin (ODT8-SST) (Erchegyi et al., 2008) prevented the increase of ACTH plasma levels induced by tail suspension or exposure to ether in rats (Brown et al., 1984). By contrast, the intravenous (iv) injection of ODT8SST had no effect indicating a centrally-mediated inhibitory action of somatostatin-28 (Brown et al., 1984). The somatostatin action may involve a component upstream of CRF signaling. This is most likely due to the inhibition of hypothalamic release of CRF induced by tail suspension (Brown et al., 1984). This is also supported by in vitro studies showing that octreotide 
$\left(\right.$ sst $_{5}=$ sst $_{2}>$ sst $_{3}$ agonist) (Grace et al., 2008) and the pan-sst agonists, somatostatin-14 and cortistatin $\left(\mathrm{sst}_{2}=\mathrm{sst}_{3}=\mathrm{sst}_{4}=\right.$ sst $_{5}>$ sst $_{1}$ ) (Fukusumi et al., 1997) blunt basal and KCl-induced CRF release from hypothalamic and hippocampal explants (Tizabi and Calogero, 1992; Tringali et al., 2012).

With regards to the receptor subtype(s) involved, in addition to the $s t_{5}=s_{2} t_{2}>s t_{3}$ agonist, octreotide (Tringali et al., 2012), recent studies indicate that intra-hippocampal infusion of the sst $_{2}$ agonist, L-054,264, and sst $_{4}$ agonist, L-803,087 lowered the elevated corticosterone levels in the plasma and hippocampal dialysate induced by acute foot shock in mice (Prévôt et al., 2017). By contrast, under the same conditions, the sst $_{1}$ agonist L-797,591 and sst $_{3}$ agonist, L-796,77 had no effect (Prévôt et al., 2017). The activation of these somatostin-sst 2 and - sst $_{4}$ signaling pathways was shown to have physiological relevance in dampening the hippocampal corticosterone elevation induced by acute foot shock. In $s_{2} t_{2}$ knockout mice, the rise in hippocampal corticosterone after an acute foot shock had a shorter onset, higher maximum and delayed recovery compared to wild type mice (Prévôt et al., 2017). Moreover, the sst 4 agonist microinjected into the hippocampus in sst $_{2}$ knockout mice exposed to foot shock shortened the return to basal corticosterone levels, while not influencing the elevation to the peak rise (Prévôt et al., 2017). These data point toward distinct inhibitory actions of sst subtypes with sst $_{2}$ dampening the initial stress-corticosterone response, while sst $_{4}$ activation accelerates the recovery.

It is likely that somatostatin may have an additional sst ${ }_{2}$ mediated inhibitory action at the pituitary level where ACTHsecreting cells express the sst $_{2}$ (Day et al., 1995; Mezey et al., 1998). In vitro studies showed that somatostatin-14 (Heisler et al., 1982; Richardson, 1983) and somatostatin-28 (Strowski et al., 2002) as well as selective sst ${ }_{2}$ and sst $_{5}$ agonists, unlike sst $_{1}$, sst $_{3}$, or sst $_{4}$ (Strowski et al., 2002) block the CRF-stimulated ACTH release from pituitary AtT-20 cells. Moreover, the pituitaries of sst $_{2}$ knockout mice display a higher ACTH release in vitro compared to that of wild type littermates (Viollet et al., 2000) and in vivo, sst 2 knockout mice have elevated basal levels of plasma corticosterone, while those of $s t_{4}$ knockout mice were unchanged (Prévôt et al., 2017). Taken together, the somatostatin receptors-induced reduction of HPA activation and elevation of hippocampal corticosterone in response to stress may be primarily mediated by brain $s^{2} t_{2}$ and $s t_{4}$ and pituitary $s_{2}$ (Figure 1).

\section{Autonomic Response}

Convergent reports in rats indicate that the activation of brain somatostatin signaling blocked the stress-related sympathetic activation. Brown et al. initially showed that icv injection of somatostatin-28 or ODT8-SST abolished the plasma epinephrine elevation elicited by a variety of stressors including acute exposure to tail suspension, intermittent loud noise, ether stress, or metabolic hypoglycemic stress induced by the injection of 2deoxyglucose or insulin in rats (Fisher and Brown, 1980; Brown et al., 1982, 1984; Gotoh et al., 2001).

The centrally mediated action of the SST-agonists was demonstrated by the lack of effect when ODT8-SST was administered peripherally at a dose 100-times higher than icv (Fisher and Brown, 1980; Gotoh et al., 2001). Microinjection of ODT8-SST into specific brain nuclei further established that the dorsal hypothalamic area is a brain site responsive to suppress elevated epinephrine secretion in dogs (Brown, 1983). In addition, the direct electrophysiological recording in the adrenal branch of the splanchnic nerve corroborated that icv injection of somatostatin suppresses adrenal sympathetic efferent activity in rats (Somiya and Tonoue, 1984).

With regards to the somatostatin receptor subtype(s) involved, icv injection of octreotide $\left(s t_{5}=s s t_{2}>s s t_{3}\right)$ prevented the rise in serum catecholamines induced by 2-deoxyglucose and short exposure to cold swim stress (Gotoh et al., 2001). Recent neuroanatomical and electrophysiological findings support a role of the $s_{2} t_{2}$ to induce sympathoinhibitory actions in presympathetic neurons located in the rostroventrolateral medulla (RVLM). The sst $_{2 \mathrm{a}}$ is the receptor most abundantly expressed at this site compared to other subtypes and microinjection of somatostatin into the RVLM induces a sympatho-inhibitory response mimicked by the $s_{2} t_{2}$ agonist, lanreotide and prevented by an sst $_{2}$ antagonist, BIM-23627 in rats (Burke et al., 2008).

\section{Behavioral Response-Focus on Food Intake}

Brain CRF receptors are involved in the stress-related reduction of food intake in rodents (Krahn et al., 1986; Shibasaki et al., 1988b) through the activation of both $\mathrm{CRF}_{1}$ and $\mathrm{CRF}_{2}$ (Hotta et al., 1999; Sekino et al., 2004; Stengel and Taché, 2014b). This inhibitory effect is counteracted by brain somatostatin as the pansst agonists, somatostatin-14 and somatostatin-28 or the oligosomatostatin agonist, octreotide injected icv blunted the icv CRFinduced reduction of refeeding after a fast in rats (Shibasaki et al., 1988a). Moreover, somatostatin-14 and octreotide also blocked the robust anorexigenic response to restraint stress (Shibasaki et al., 1988b). Likewise, we reported that the intracisternal (ic) injection of ODT8-SST prevented the inhibition of food intake induced after abdominal surgery in fasted rats (Stengel et al., 2011b). This effect is recapitulated by the selective peptide $s_{2} t_{2}$ agonist, S-346-011 (Stengel et al., 2011b; Figure 1). We also found that ic ODT8-SST or an sst $_{2}$ agonist, unlike selective sst $_{1}$ or sst $_{4}$ agonists, restored plasma levels of the orexigenic hormone, acyl ghrelin (Hosoda et al., 2002) that were inhibited by abdominal surgery (Stengel et al., 2011b). However, the restoration of food intake after surgery by ic ODT8-SST is not secondary to the normalization of circulating acyl ghrelin as the ghrelin receptor antagonist, [D-Lys ${ }^{3}$ ]-GHRP-6 injected intraperitoneally (ip) did not alter ic ODT8-SST's action (Stengel et al., 2011b).

We previously established that abdominal surgery activates hypothalamic CRF neurons (Bonaz and Taché, 1997; Wang et al., 2011). Therefore, it may be speculated that the activation of brain sst $_{2}$ by ic ODT8-SST suppresses brain CRF release and the related inhibition of food intake (Stengel and Taché, 2014b). Whether the recently established robust dipsogenic response to brain $s^{2} t_{2}$ activation (Karasawa et al., 2014) also contributes to the increased 


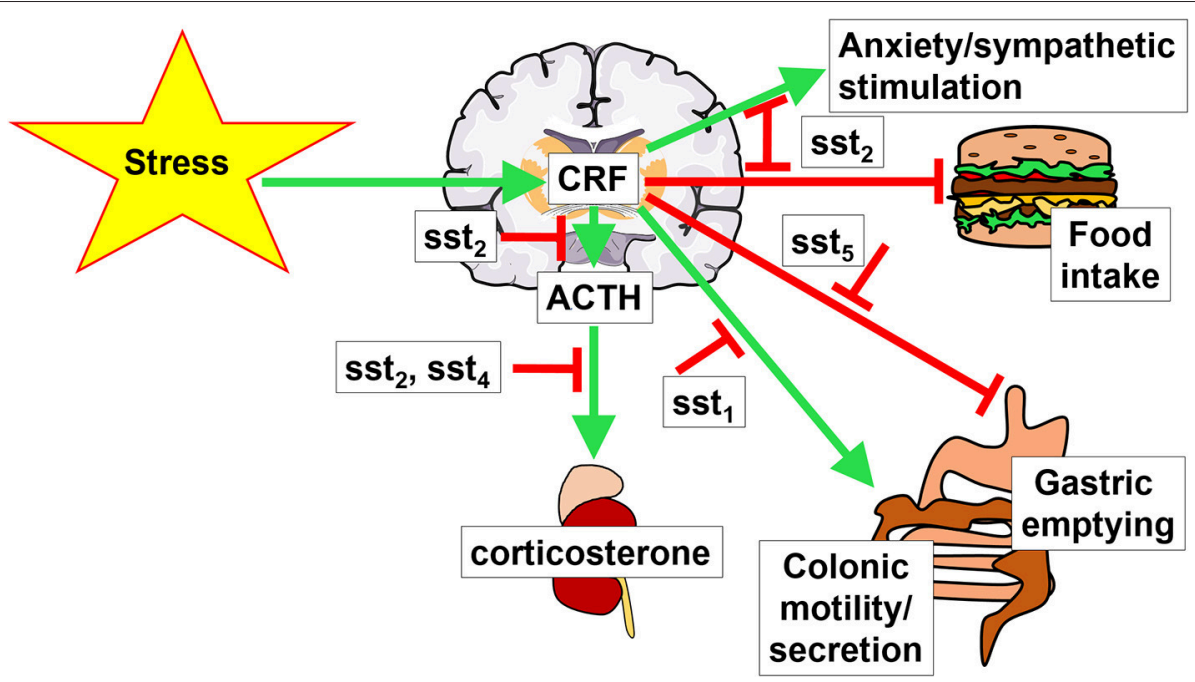

FIGURE 1 | Brain interaction of CRF and somatostatin signaling. Stress activates the hypothalamus-pituitary-adrenal gland axis by stimulating the hormones corticotropin-releasing factor (CRF), adrenocorticotropic hormone (ACTH) and corticosterone. This stimulation is modulated by somatostatin signaling via different somatostatin receptors (sst). Green arrows indicate a stimulatory effect, red arrows depict an inhibition.

feeding behavior (Kissileff, 1969) inhibited by stress will have to be further investigated.

\section{Visceral Response-Focus on Gastrointestinal Motor Functions}

A multitude of stressors (physical, psychological, and immunological) alter gastrointestinal transit resulting in an inhibitory effect in the upper gastrointestinal tract, while stimulating colonic propulsive motor function (Stengel and Taché, 2009). These effects involve the activation of brain CRF receptors (Taché and Bonaz, 2007). Likewise, CRF and urocortin 1 injected into the brain ventricle or paraventricular nucleus of the hypothalamus suppress gastric emptying (Taché et al., 1987; Mönnikes et al., 1992; Coskun et al., 1997; Lee and Sarna, 1997) and shorten colonic transit time (Mönnikes et al., 1993; Martinez and Taché, 2001). Conversely, the blockade of CRF receptor signaling, namely $\mathrm{CRF}_{2}$ and/or $\mathrm{CRF}_{1}$ in the upper and $\mathrm{CRF}_{1}$ in the lower gastrointestinal tract, prevented the delayed gastric emptying and the stimulation of colonic motility and defecation induced by various stressors in rodents (Taché and Bonaz, 2007).

By contrast to the ic injection of CRF, that of the pansst agonist, ODT8-SST accelerates gastric emptying in rats, an effect recapitulated by the preferential sst ${ }_{5}$ agonist, BIM23052 injected ic and blocked by subdiaphragmatic vagotomy or atropine (Martinez et al., 2000). The sst ${ }_{5}$ is likely the main receptor mediating this action as ic injection of the selective sst $_{1}$, sst $_{2}$, sst $_{3}$ or sst $_{4}$ agonists CH-275, DC-32-87, BIM-23056 and L-803,087, respectively did not modify gastric emptying (Martinez et al., 2000). Lastly, intravenous (iv) injection of the predominant sst ${ }_{5}$ agonist, BIM-23052 had no effect (Martinez et al., 2000). The prominent expression of the sst ${ }_{5}$ in the dorsal motor nucleus of the vagus nerve (Thoss et al., 1995) along with functional data are consistent with the activation of the sst ${ }_{5}$ in the hindbrain inducing a vagal cholinergic-dependent stimulation of gastric propulsive motor function (Martinez et al., 2000). The sst $_{5}$ has been shown to form heterodimers with sst $_{1}$ or sst $_{2}$ that potentiates signaling efficiency (Rocheville et al., 2000). Whether ODT8-SST acts through these heterodimers cannot be ruled out. In addition, as the $\mu$ opioid receptor antagonist, naloxone was shown to block the ODT8-SST-induced acceleration of gastric emptying in rats (Stengel et al., 2010), it will be important to investigate whether heterodimers of the sst ${ }_{5}$ with the $\mu$ opioid receptor also expressed in the dorsal motor nucleus (Mansour et al., 1995) occur as shown before with the $s_{2 a}$ (Pfeiffer et al., 2002).

Under stress conditions, the activation of somatostatin receptors restores the inhibited gastric emptying. Abdominal surgery is a well-established physical stressor suppressing the initial neurogenic phase of postoperative gastric ileus through activation of brain CRF signaling (Luckey et al., 2003a; Stengel and Taché, 2014a). We showed that injection of somatostatin-28 icv and ODT8-SST icv or ic prevented the abdominal surgeryinduced delayed gastric emptying (Stengel et al., 2011b). This effect is mimicked by ic injection of the selective sst ${ }_{5}$ agonist, BIM-23052, while under the same conditions, ic injection of sst (S-406-062), sst 2 (S-346-011), or sst 4 (S315-297) peptide agonists had no effect (Stengel et al., 2011b). It is important to note that the prevention of surgery-induced inhibition of the prokinetic hormone acyl ghrelin (De Smet et al., 2009) by ic ODT8-SST primarily involves the $s_{2}{ }_{2}$ (Stengel et al., 2011b). Additionally, we demonstrated that blockade of ghrelin signaling using the ghrelin receptor antagonist, [D-Lys ${ }^{3}$-GHRP-6 did not modify the ODT8-SST-induced prevention of postoperative gastric ileus (Stengel et al., 2011b). Taken together these data argue against the preventive action of ic ODT8-SST against postoperative gastric ileus being secondary to the normalization of circulating 
prokinetic hormone acyl ghrelin. The mechanisms may involve stimulation of vagal efferent activity and/or an interaction with other transmitters such as opioids that will have to be further established.

Several stressors exert a brain $\mathrm{CRF}_{1}$-mediated stimulatory action on colonic motor functions in rodents (Taché and Million, 2015). The activation of brain somatostatin signaling inhibits the colonic response to exogenously administered CRF or CRF endogenously released by stress (Stengel et al., 2011a). We reported that icv injection of ODT8-SST inhibits the icv CRF- and water avoidance stress-induced increased fecal pellet output and colonic contractions evoked by semi-restraint in mice (Stengel et al., 2011a). Pharmacological characterization of receptor supports a primary involvement of the $s t_{1}$. Acute anesthesia stress in mice, that led to a pronounced increase of fecal pellet output, is inhibited by icv injection of somatostatin28 and ODT8-SST or the selective peptide sst $_{1}$ agonist, S-406-062 (Stengel et al., 2011a). In contrast, the oligo-sst agonist, octreotide $\left(\right.$ sst $_{5}=$ sst $_{2}>$ sst $\left._{3}\right)$ or selective peptide sst $_{2}$ or $_{\text {sst }}$ agonists, S-346011 and S-315-297, respectively did not modify the acute stressinduced stimulation of fecal pellet output (Stengel et al., 2011a). This assumption is further corroborated by the expression of this receptor (among other receptors) in the hypothalamus and the brainstem (Fehlmann et al., 2000) in nuclei modulating colonic motility.

\section{SUMMARY}

Mounting evidence supports that the activation of brain sst alleviates many components of the stress response involving brain CRF signaling. The receptor subtype(s) have been characterized by the use of selective peptide agonists and antagonists or genetic manipulations in rodents. The sst 2 subtype is primarily involved in preventing the acute stress-induced

\section{REFERENCES}

Arancibia, S., Epelbaum, J., Boyer, R., and Assenmacher, I. (1984). In vivo release of somatostatin from rat median eminence after local $\mathrm{K}^{+}$infusion or delivery of nociceptive stress. Neurosci. Lett. 50, 97-102. doi: 10.1016/0304-3940(84) 90469-5

Arancibia, S., Payet, O., Givalois, L., and Tapia-Arancibia, L. (2001). Acute stress and dexamethasone rapidly increase hippocampal somatostatin synthesis and release from the dentate gyrus hilus. Hippocampus 11, 469-477. doi: 10.1002/hipo.1061

Arancibia, S., Rage, F., Grauges, P., Gomez, F., Tapia-Arancibia, L., and Armario, A. (2000). Rapid modifications of somatostatin neuron activity in the periventricular nucleus after acute stress. Exp. Brain Res. 134, 261-267. doi: $10.1007 /$ s002210000462

Bale, T. L., and Chen, A. (2012). Minireview: CRF and Wylie Vale: a story of 41 amino acids and a Texan with grit. Endocrinology 153, 2556-2561. doi: 10.1210/en.2012-1273

Bale, T. L., and Vale, W. W. (2004). CRF and CRF receptors: role in stress responsivity and other behaviors. Annu. Rev. Pharmacol. Toxicol. 44, 525-557. doi: 10.1146/annurev.pharmtox.44.101802. 121410

Bali, A., Singh, N., and Jaggi, A. S. (2014). Neuropeptides as therapeutic targets to combat stress-associated behavioral and neuroendocrinological effects. CNS Neurol. Disord. Drug Targets 13, 347-368. doi: $10.2174 / 1871527313666140314163920$ endocrine (rise of ACTH and corticosterone), autonomic (sympatho-inhibition) and behavioral (suppression of food intake and anxiety) responses. With regards to the braingut axis, the hindbrain sst 5 plays a key role in counteracting the stress-induced suppression of gastric emptying, whereas forebrain sst $_{1}$ reduces the stress-related stimulation of propulsive colonic motor function (Figure 1). These data provide clear evidence that exogenous activation of brain sst receptors by pharmacological administration of somatostatin and selective agonists have anti-stress properties; however, the role of endogenous brain somatostatin released by stress (Arancibia et al., 1984, 2000) or exogenous CRF (Mitsugi et al., 1990) in attenuating or terminating the stress response has still been little investigated (Prévôt et al., 2017). Likewise, our knowledge of specific brain sites through which selective activation of somatostatin receptors alleviates the stress response is still limited to sst $_{2}$ signaling in the hippocampus to suppress the rise in plasma corticosterone and to induce anxiolytic behavior (Prévôt et al., 2017) and in the RVLM to elicit sympatho-inhibition (Pilowsky et al., 2008; Prévôt et al., 2017).

\section{AUTHOR CONTRIBUTIONS}

All authors listed, have made substantial, direct and intellectual contribution to the work, and approved it for publication.

\section{ACKNOWLEDGMENTS}

This work was supported by funding of the German Research Foundation STE 1765/3-2, Charité University Funding UFF 89/441-176 (AS) and National Institute of Health grants (R01 DK -57238), P30 Center grant DK-41301 (Animal Model Core) and VA Senior Career Scientist Award (YT).

Bardgett, M. E., Sharpe, A. L., and Toney, G. M. (2014). Activation of corticotropin-releasing factor receptors in the rostral ventrolateral medulla is required for glucose-induced sympathoexcitation. Am. J. Physiol. Endocrinol. Metab. 307, E944-E953. doi: 10.1152/ajpendo.00291.2014

Bittencourt, J. C., and Sawchenko, P. E. (2000). Do centrally administered neuropeptides access cognate receptors? An analysis in the central corticotropin-releasing factor system. J. Neurosci. 20, 1142-1156.

Bittencourt, J. C., Vaughan, J., Arias, C., Rissman, R. A., Vale, W. W., and Sawchenko, P. E. (1999). Urocortin expression in rat brain: evidence against a pervasive relationship of urocortin-containing projections with targets bearing type 2 CRF receptors. J. Comp. Neurol. 415, 285-312.

Bonaz, B., and Rivest, S. (1998). Effect of a chronic stress on CRF neuronal activity and expression of its type 1 receptor in the rat brain. Am. J. Physiol. 275, R1438-R1449.

Bonaz, B., and Taché, Y. (1997). Corticotropin-releasing factor and systemic capsaicin-sensitive afferents are involved in abdominal surgery-induced Fos expression in the paraventricular nucleus of the hypothalamus. Brain Res. 748, 12-20. doi: 10.1016/S0006-8993(96)01281-4

Bou Farah, L., Bowman, B. R., Bokiniec, P., Karim, S., Le, S., Goodchild, A. K., et al. (2016). Somatostatin in the rat rostral ventrolateral medulla: origins and mechanism of action. J. Comp. Neurol. 524, 323-342. doi: 10.1002/cne.23846

Brazeau, P., Vale, W., Burgus, R., Ling, N., Butcher, M., Rivier, J., et al. (1973). Hypothalamic polypeptide that inhibits the secretion of immunoreactive pituitary growth hormone. Science 179, 77-79. doi: $10.1126 /$ science.179.4068.77 
Brown, M. R. (1983). Central nervous system sites of action of bombesin and somatostatin to influence plasma epinephrine levels. Brain Res. 276, 253-257. doi: 10.1016/0006-8993(83)90732-1

Brown, M. R., Fisher, L. A., Spiess, J., Rivier, C., Rivier, J., and Vale, W. (1982). Corticotropin-releasing factor: actions on the sympathetic nervous system and metabolism. Endocrinology 111, 928-931. doi: 10.1210/endo-111-3-928

Brown, M. R., Rivier, C., and Vale, W. (1984). Central nervous system regulation of adrenocorticotropin secretion: role of somatostatins. Endocrinology 114, 1546-1549. doi: 10.1210/endo-114-5-1546

Brown, M., and Taché, Y. (1981). Hypothalamic peptides: central nervous system control of visceral functions. Fed. Proc. 40, 2565-2569.

Burke, P. G., Li, Q., Costin, M. L., McMullan, S., Pilowsky, P. M., and Goodchild, A. K. (2008). Somatostatin $2 \mathrm{~A}$ receptor-expressing presympathetic neurons in the rostral ventrolateral medulla maintain blood pressure. Hypertension 52, 1127-1133. doi: 10.1161/HYPERTENSIONAHA.108.118224

Butler, R. K., White, L. C., Frederick-Duus, D., Kaigler, K. F., Fadel, J. R., and Wilson, M. A. (2012). Comparison of the activation of somatostatinand neuropeptide Y-containing neuronal populations of the rat amygdala following two different anxiogenic stressors. Exp. Neurol. 238, 52-63. doi: 10.1016/j.expneurol.2012.08.002

Chen, N. A., Jupp, B., Sztainberg, Y., Lebow, M., Brown, R. M., Kim, J. H., et al. (2014). Knockdown of CRF1 receptors in the ventral tegmental area attenuates cue- and acute food deprivation stress-induced cocaine seeking in mice. J. Neurosci. 34, 11560-11570. doi: 10.1523/JNEUROSCI.4763-12.2014

Chen, X. Q., and Du, J. Z. (2002). Increased somatostatin mRNA expression in periventricular nucleus of rat hypothalamus during hypoxia. Regul. Pept. 105, 197-201. doi: 10.1016/S0167-0115(02)00022-8

Chrousos, G. P., and Zoumakis, E. (2017). Milestones in CRH research. Curr. Mol. Pharmacol. [Epub ahead of print].

Cole, S. L., and Schindler, M. (2000). Characterisation of somatostatin sst2 receptor splice variants. J. Physiol. Paris. 94, 217-237. doi: 10.1016/S0928-4257(00)00207-2

Cordoba-Chacon, J., Gahete, M. D., Duran-Prado, M., Luque, R. M., and Castano, J. P. (2011). Truncated somatostatin receptors as new players in somatostatin-cortistatin pathophysiology. Ann. N.Y. Acad. Sci. 1220, 6-15. doi: 10.1111/j.1749-6632.2011.05985.x

Cordoba-Chacon, J., Gahete, M. D., Duran-Prado, M., Pozo-Salas, A. I., Malagon, M. M., Gracia-Navarro, F., et al. (2010). Identification and characterization of new functional truncated variants of somatostatin receptor subtype 5 in rodents. Cell Mol. Life Sci. 67, 1147-1163. doi: 10.1007/s00018-0090240-y

Coskun, T., Bozkurt, A., Alican, I., Ozkutlu, U., Kurtel, H., and Yegen, B. C. (1997). Pathways mediating CRF-induced inhibition of gastric emptying in rats. Regul. Pept. 69, 113-120. doi: 10.1016/S0167-0115(96)02066-6

Day, R., Dong, W., Panetta, R., Kraicer, J., Greenwood, M. T., and Patel, Y. C. (1995). Expression of mRNA for somatostatin receptor (sstr) types 2 and 5 in individual rat pituitary cells. A double labeling in situ hybridization analysis. Endocrinology 136, 5232-5235.

de Groot, J., and Harris, G. W. (1950). Hypothalmic control of the anterior pituitary gland and blood lymphocytes. J. Physiol. 111, 335-346. doi: 10.1113/jphysiol.1950.sp004483

de Lecea, L., Criado, J. R., Prospero-Garcia, O., Gautvik, K. M., Schweitzer, P., Danielson, P. E., et al. (1996). A cortical neuropeptide with neuronal depressant and sleep-modulating properties. Nature 381, 242-245. doi: 10.1038/381242a0

De Smet, B., Mitselos, A., and Depoortere, I. (2009). Motilin and ghrelin as prokinetic drug targets. Pharmacol. Ther. 123, 207-223. doi: 10.1016/j.pharmthera.2009.04.004

Duran-Prado, M., Gahete, M. D., Delgado-Niebla, E., Martinez-Fuentes, A. J., Vazquez-Martinez, R., Garcia-Navarro, S., et al. (2012). Truncated variants of pig somatostatin receptor subtype 5 (sst5) act as dominant-negative modulators for sst2-mediated signaling. Am. J. Physiol. Endocrinol. Metab. 303, E1325E1334. doi: 10.1152/ajpendo.00445.2012

Duran-Prado, M., Gahete, M. D., Martinez-Fuentes, A. J., Luque, R. M., Quintero, A., Webb, S. M., et al. (2009). Identification and characterization of two novel truncated but functional isoforms of the somatostatin receptor subtype 5 differentially present in pituitary tumors. J. Clin. Endocrinol. Metab. 94, 2634-2643. doi: 10.1210/jc.2008-2564
Engin, E., and Treit, D. (2009). Anxiolytic and antidepressant actions of somatostatin: the role of sst2 and sst 3 receptors. Psychopharmacology (Berl) 206, 281-289. doi: 10.1007/s00213-009-1605-5

Epelbaum, J., Guillou, J. L., Gastambide, F., Hoyer, D., Duron, E., and Viollet, C. (2009). Somatostatin, Alzheimer's disease and cognition: an old story coming of age? Prog. Neurobiol. 89, 153-161. doi: 10.1016/j.pneurobio.2009.07.002

Eraslan, E., Akyazi, I., Ergul-Ekiz, E., and Matur, E. (2015). Noise stress-induced changes in mRNA levels of corticotropin-releasing hormone family molecules and glucocorticoid receptors in the rat brain. Folia Biol. (Praha) 61, 66-73.

Erchegyi, J., Grace, C. R., Samant, M., Cescato, R., Piccand, V., Riek, R., et al. (2008). Ring size of somatostatin analogues (ODT-8) modulates receptor selectivity and binding affinity. J. Med. Chem. 51, 2668-2675. doi: 10.1021/jm701444y

Faron-Gorecka, A., Kusmider, M., Kolasa, M., Zurawek, D., Szafran-Pilch, K., Gruca, P., et al. (2016). Chronic mild stress alters the somatostatin receptors in the rat brain. Psychopharmacology (Berl) 233, 255-266. doi: 10.1007/s00213-015-4103-y

Farrokhi, C. B., Tovote, P., Blanchard, R. J., Blanchard, D. C., Litvin, Y., and Spiess, J. (2007). Cortagine: behavioral and autonomic function of the selective CRF receptor subtype 1 agonist. CNS Drug Rev. 13, 423-443. doi: 10.1111/j.1527-3458.2007.00027.x

Fehlmann, D., Langenegger, D., Schuepbach, E., Siehler, S., Feuerbach, D., and Hoyer, D. (2000). Distribution and characterisation of somatostatin receptor mRNA and binding sites in the brain and periphery. J. Physiol. Paris 94, 265-281. doi: 10.1016/S0928-4257(00)00208-4

Finley, J. C., Maderdrut, J. L., Roger, L. J., and Petrusz, P. (1981). The immunocytochemical localization of somatostatin-containing neurons in the rat central nervous system. Neuroscience 6, 2173-2192. doi: 10.1016/0306-4522(81)90006-3

Fisher, D. A., and Brown, M. R. (1980). Somatostatin analog: plasma catecholamine suppression mediated by the central nervous system. Endocrinology 107, 714-718. doi: 10.1210/endo-107-3-714

Fukusumi, S., Kitada, C., Takekawa, S., Kizawa, H., Sakamoto, J., Miyamoto, M., et al. (1997). Identification and characterization of a novel human cortistatin-like peptide. Biochem. Biophys. Res. Commun. 232, 157-163. doi: 10.1006/bbrc.1997.6252

Gahete, M. D., Duran-Prado, M., Luque, R. M., Martinez-Fuentes, A. J., VazquezMartinez, R., Malagon, M. M., et al. (2008). Are somatostatin and cortistatin two siblings in regulating endocrine secretions? In vitro work ahead. Mol. Cell. Endocrinol. 286, 128-134. doi: 10.1016/j.mce.2007.11.013

Gastambide, F., Viollet, C., Lepousez, G., Epelbaum, J., and Guillou, J. L. (2009). Hippocampal SSTR4 somatostatin receptors control the selection of memory strategies. Psychopharmacology (Berl) 202, 153-163. doi: 10.1007/s00213-008-1204-x

Gonzalez-Rey, E., Pedreno, M., Delgado-Maroto, V., Souza-Moreira, L., and Delgado, M. (2015). Lulling immunity, pain, and stress to sleep with cortistatin. Ann. N.Y. Acad. Sci. 1351, 89-98. doi: 10.1111/nyas.12789

Gotoh, M., Takagi, J., Mori, S., Yatoh, M., Hirooka, Y., Yamanouchi, K., et al. (2001). Octreotide-induced suppression of the hyperglycemic response to neostigmine or bombesin: relationship to hypothalamic noradrenergic drive. Brain Res. 919, 155-159. doi: 10.1016/S0006-8993(01)03018-9

Grace, C. R., Erchegyi, J., Samant, M., Cescato, R., Piccand, V., Riek, R., et al. (2008). Ring size in octreotide amide modulates differently agonist versus antagonist binding affinity and selectivity. J. Med. Chem. 51, 2676-2681. doi: $10.1021 / \mathrm{jm} 701445 \mathrm{q}$

Grace, C. R., Perrin, M. H., Cantle, J. P., Vale, W. W., Rivier, J. E., and Riek, R. (2007). Common and divergent structural features of a series of corticotropin releasing factor-related peptides. J. Am. Chem. Soc. 129, 16102-16114. doi: 10.1021/ja0760933

Grammatopoulos, D. K. (2012). Insights into mechanisms of corticotropinreleasing hormone receptor signal transduction. Br. J. Pharmacol. 166, 85-97. doi: 10.1111/j.1476-5381.2011.01631.x

Grammatopoulos, D. K., Dai, Y., Randeva, H. S., Levine, M. A., Karteris, E., Easton, A. J., et al. (1999). A novel spliced variant of the type 1 corticotropin-releasing hormone receptor with a deletion in the seventh transmembrane domain present in the human pregnant term myometrium and fetal membranes. Mol. Endocrinol. 13, 2189-2202. doi: 10.1210/mend.13.12.0391 
Gravanis, A., and Margioris, A. N. (2005). The corticotropin-releasing factor (CRF) family of neuropeptides in inflammation: potential therapeutic applications. Curr. Med. Chem. 12, 1503-1512. doi: 10.2174/0929867054039008

Guillemin, R., and Rosenberg, B. (1955). Humoral hypothalamic control of anterior pituitary: a study with combined tissue cultures. Endocrinology 57, 599-607. doi: 10.1210/endo-57-5-599

Hannon, J. P., Nunn, C., Stolz, B., Bruns, C., Weckbecker, G., Lewis, I., et al. (2002a). Drug design at peptide receptors: somatostatin receptor ligands. J. Mol. Neurosci. 18, 15-27. doi: 10.1385/JMN:18:1-2:15

Hannon, J. P., Petrucci, C., Fehlmann, D., Viollet, C., Epelbaum, J., and Hoyer, D. (2002b). Somatostatin sst2 receptor knock-out mice: localisation of sst15 receptor mRNA and binding in mouse brain by semi-quantitative RTPCR, in situ hybridisation histochemistry and receptor autoradiography. Neuropharmacology 42, 396-413. doi: 10.1016/S0028-3908(01)00186-1

Harris, G. W. (1950). The hypothalamus and endocrine glands. Br. Med. Bull. 6, 345-350. doi: 10.1093/oxfordjournals.bmb.a073628

Heisler, S., Reisine, T. D., Hook, V. Y., and Axelrod, J. (1982). Somatostatin inhibits multireceptor stimulation of cyclic AMP formation and corticotropin secretion in mouse pituitary tumor cells. Proc. Natl. Acad. Sci. U.S.A. 79, 6502-6506. doi: 10.1073/pnas.79.21.6502

Henckens, M. J., Printz, Y., Shamgar, U., Dine, J., Lebow, M., Drori, Y., et al. (2016). CRF receptor type 2 neurons in the posterior bed nucleus of the stria terminalis critically contribute to stress recovery. Mol. Psychiatry. doi: 10.1038/mp.2016.133. [Epub ahead of print].

Hillhouse, E. W., and Grammatopoulos, D. K. (2006). The molecular mechanisms underlying the regulation of the biological activity of corticotropin-releasing hormone receptors: implications for physiology and pathophysiology. Endocr. Rev. 27, 260-286. doi: 10.1210/er.2005-0034

Hosoda, H., Kojima, M., and Kangawa, K. (2002). Ghrelin and the regulation of food intake and energy balance. Mol. Interv. 2, 494-503. doi: 10.1124/mi.2.8.494

Hotta, M., Shibasaki, T., Arai, K., and Demura, H. (1999). Corticotropinreleasing factor receptor type 1 mediates emotional stress-induced inhibition of food intake and behavioral changes in rats. Brain Res. 823, 221-225. doi: 10.1016/S0006-8993(99)01177-4

Imaki, T., Katsumata, H., Miyata, M., Naruse, M., Imaki, J., and Minami, S. (2001). Expression of corticotropin-releasing hormone type 1 receptor in paraventricular nucleus after acute stress. Neuroendocrinology 73, 293-301. doi: $10.1159 / 000054646$

Johansson, O., Hokfelt, T., and Elde, R. P. (1984). Immunohistochemical distribution of somatostatin-like immunoreactivity in the central nervous system of the adult rat. Neuroscience 13, 265-339. doi: 10.1016/0306-4522(84)90233-1

Justice, N. J., Yuan, Z. F., Sawchenko, P. E., and Vale, W. (2008). Type 1 corticotropin-releasing factor receptor expression reported in BAC transgenic mice: implications for reconciling ligand-receptor mismatch in the central corticotropin-releasing factor system. J. Comp. Neurol. 511, 479-496. doi: $10.1002 / \mathrm{cne} .21848$

Kageyama, K., and Suda, T. (2009). Role and action in the pituitary corticotroph of corticotropin-releasing factor (CRF) in the hypothalamus. Peptides 30, 810-816. doi: 10.1016/j.peptides.2008.12.007

Karasawa, H., Yakabi, S., Wang, L., Stengel, A., Rivier, J., and Taché, Y. (2014). Brain somatostatin receptor 2 mediates the dipsogenic effect of central somatostatin and cortistatin in rats: role in drinking behavior. Am. J. Physiol. Regul. Integr. Comp. Physiol. 307, R793-R801. doi: 10.1152/ajpregu.00248.2014

Kehne, J. H., and Cain, C. K. (2010). Therapeutic utility of non-peptidic CRF1 receptor antagonists in anxiety, depression, and stress-related disorders: evidence from animal models. Pharmacol. Ther. 128, 460-487. doi: $10.1016 /$ j.pharmthera.2010.08.011

Kissileff, H. R. (1969). Food-associated drinking in the rat. J. Comp. Physiol. Psychol. 67, 284-300. doi: 10.1037/h0026773

Konishi, S., Kasagi, Y., Katsumata, H., Minami, S., and Imaki, T. (2003). Regulation of corticotropin-releasing factor (CRF) type-1 receptor gene expression by CRF in the hypothalamus. Endocr. J. 50, 21-36. doi: 10.1507/endocrj.50.21

Korosi, A., Kozicz, T., Richter, J., Veening, J. G., Olivier, B., and Roubos, E. W. (2007). Corticotropin-releasing factor, urocortin 1 , and their receptors in the mouse spinal cord. J. Comp. Neurol. 502, 973-989. doi: 10.1002/cne.21347
Krahn, D. D., Gosnell, B. A., Grace, M., and Levine, A. S. (1986). CRF antagonist partially reverses CRF- and stress-induced effects on feeding. Brain Res. Bull. 17, 285-289. doi: 10.1016/0361-9230(86)90233-9

Kuhne, C., Puk, O., Graw, J., Hrabe De Angelis, M., Schutz, G., Wurst, W., et al. (2012). Visualizing corticotropin-releasing hormone receptor type 1 expression and neuronal connectivities in the mouse using a novel multifunctional allele. J. Comp. Neurol. 520, 3150-3180. doi: 10.1002/cne.23082

Kumar, U. (2012). Immunohistochemical distribution of somatostatin and somatostatin receptor subtypes (SSTR1-5) in hypothalamus of ApoD knockout mice brain. J. Mol. Neurosci. 48, 684-695. doi: 10.1007/s12031-012-9792-7

Lee, C., and Sarna, S. K. (1997). Central regulation of gastric emptying of solid nutrient meals by corticotropin releasing factor. Neurogastroenterol. Motil. 9 , 221-229. doi: 10.1046/j.1365-2982.1997.d01-58.x

Lewis, K., Li, C., Perrin, M. H., Blount, A., Kunitake, K., Donaldson, C., et al. (2001). Identification of urocortin III, an additional member of the corticotropin-releasing factor (CRF) family with high affinity for the CRF2 receptor. Proc. Natl. Acad. Sci. U.S.A. 98, 7570-7575. doi: $10.1073 /$ pnas. 121165198

Li, C., Vaughan, J., Sawchenko, P. E., and Vale, W. W. (2002). Urocortin IIIimmunoreactive projections in rat brain: partial overlap with sites of type 2 corticotrophin-releasing factor receptor expression. J. Neurosci. 22, 991-1001.

Liguz-Lecznar, M., Urban-Ciecko, J., and Kossut, M. (2016). Somatostatin and somatostatin-containing neurons in shaping neuronal activity and plasticity. Front. Neural. Circuits 10:48. doi: 10.3389/fncir.2016.00048

Lovejoy, D. A., and de Lannoy, L. (2013). Evolution and phylogeny of the corticotropin-releasing factor (CRF) family of peptides: expansion and specialization in the vertebrates. J. Chem. Neuroanat. 54, 50-56. doi: 10.1016/j.jchemneu.2013.09.006

Luckey, A., Livingston, E., and Taché, Y. (2003a). Mechanisms and treatment of postoperative ileus. Arch. Surg. 138, 206-214. doi: 10.1001/archsurg.138.2.206

Luckey, A., Wang, L., Jamieson, P. M., Basa, N. R., Million, M., Czimmer, J., et al. (2003b). Corticotropin-releasing factor receptor 1-deficient mice do not develop postoperative gastric ileus. Gastroenterology 125, 654-659. doi: 10.1016/S0016-5085(03)01069-2

Lukkes, J. L., Staub, D. R., Dietrich, A., Truitt, W., Neufeld-Cohen, A., Chen, A., et al. (2011). Topographical distribution of corticotropin-releasing factor type 2 receptor-like immunoreactivity in the rat dorsal raphe nucleus: co-localization with tryptophan hydroxylase. Neuroscience 183, 47-63. doi: 10.1016/j.neuroscience.2011.03.047

Mano-Otagiri, A., and Shibasaki, T. (2004). Distribution of urocortin 2 and urocortin 3 in rat brain. J. Nippon Med. Sch. 71, 358-359. doi: $10.1272 /$ jnms.71.358

Mansour, A., Fox, C. A., Burke, S., Akil, H., and Watson, S. J. (1995). Immunohistochemical localization of the cloned mu opioid receptor in the rat CNS. J. Chem. Neuroanat. 8, 283-305. doi: 10.1016/0891-0618(95)00055-C

Martinez, V., Rivier, J., Coy, D., and Taché, Y. (2000). Intracisternal injection of somatostatin receptor 5-preferring agonists induces a vagal cholinergic stimulation of gastric emptying in rats. J. Pharmacol. Exp. Ther. 293, 1099-1105.

Martinez, V., and Taché, Y. (2001). Role of CRF receptor 1 in central CRFinduced stimulation of colonic propulsion in rats. Brain Res. 893, 29-35. doi: 10.1016/S0006-8993(00)03277-7

Mezey, E., Hunyady, B., Mitra, S., Hayes, E., Liu, Q., Schaeffer, J., et al. (1998). Cell specific expression of the sst $2 \mathrm{~A}$ and sst 5 somatostatin receptors in the rat anterior pituitary. Endocrinology 139, 414-419. doi: 10.1210/endo.139.1.5807

Mitsugi, N., Arita, J., and Kimura, F. (1990). Effects of intracerebroventricular administration of growth hormone-releasing factor and corticotropinreleasing factor on somatostatin secretion into rat hypophysial portal blood. Neuroendocrinology 51, 93-96. doi: 10.1159/000125322

Moga, M. M., and Gray, T. S. (1985). Evidence for corticotropin-releasing factor, neurotensin, and somatostatin in the neural pathway from the central nucleus of the amygdala to the parabrachial nucleus. J. Comp. Neurol. 241, 275-284. doi: 10.1002/cne.902410304

Mönnikes, H., Raybould, H. E., Schmidt, B., and Taché, Y. (1993). CRF in the paraventricular nucleus of the hypothalamus stimulates colonic motor activity in fasted rats. Peptides 14, 743-747. doi: 10.1016/0196-9781(93)90107-R 
Mönnikes, H., Schmidt, B. G., Raybould, H. E., and Taché, Y. (1992). CRF in the paraventricular nucleus mediates gastric and colonic motor response to restraint stress. Am. J. Physiol. 262, G137-G143.

Nanda, S. A., Qi, C., Roseboom, P. H., and Kalin, N. H. (2008). Predator stress induces behavioral inhibition and amygdala somatostatin receptor 2 gene expression. Genes Brain Behav. 7, 639-648. doi: 10.1111/j.1601-183X.2008.00401.x

Negro-Vilar, A., and Saavedra, J. M. (1980). Changes in brain somatostatin and vasopressin levels after stress in spontaneously hypertensive and Wistar-Kyoto rats. Brain Res. Bull. 5, 353-358. doi: 10.1016/S0361-9230(80)80004-9

Perrin, M. H., and Vale, W. W. (1999). Corticotropin releasing factor receptors and their ligand family. Ann. N.Y. Acad. Sci. 885, 312-328. doi: 10.1111/j.1749-6632.1999.tb08687.x

Pfeiffer, M., Koch, T., Schroder, H., Laugsch, M., Hollt, V., and Schulz, S. (2002). Heterodimerization of somatostatin and opioid receptors cross-modulates phosphorylation, internalization, and desensitization. J. Biol. Chem. 277, 19762-19772. doi: 10.1074/jbc.M110373200

Pilowsky, P. M., Abbott, S. B., Burke, P. G., Farnham, M. M., Hildreth, C. M., Kumar, N. N., et al. (2008). Metabotropic neurotransmission and integration of sympathetic nerve activity by the rostral ventrolateral medulla in the rat. Clin. Exp. Pharmacol. Physiol. 35, 508-511. doi: 10.1111/j.1440-1681.2008.04906.x

Pisarchik, A., and Slominski, A. T. (2001). Alternative splicing of CRH-R1 receptors in human and mouse skin: identification of new variants and their differential expression. Faseb J. 15, 2754-2756. doi: 10.1096/fj.01-0487fje

Polkowska, J., and Wankowska, M. (2010). Effects of maternal deprivation on the somatotrophic axis and neuropeptide $\mathrm{Y}$ in the hypothalamus and pituitary in female lambs. The histomorphometric study. Folia Histochem. Cytobiol. 48, 299-305. doi: 10.2478/v10042-010-0024-0

Pradayrol, L., Jornvall, H., Mutt, V., and Ribet, A. (1980). N-terminally extended somatostatin: the primary structure of somatostatin-28. FEBS Lett. 109, 55-58. doi: 10.1016/0014-5793(80)81310-X

Prévôt, T. D., Gastambide, F., Viollet, C., Henkous, N., Martel, G., Epelbaum, J., et al. (2017). Roles of hippocampal somatostatin receptor subtypes in stress response and emotionality. Neuropsychopharmacology. doi: 10.1038/npp.2016.281. [Epub ahead of print].

Priego, T., Ibanez De Caceres, I., Martin, A. I., Villanua, M. A., and Lopez-Calderon, A. (2005). Endotoxin administration increases hypothalamic somatostatin mRNA through nitric oxide release. Regul. Pept. 124, 113-118. doi: 10.1016/j.regpep.2004.07.001

Reichmann, F., and Holzer, P. (2016). Neuropeptide Y: a stressful review. Neuropeptides 55, 99-109. doi: 10.1016/j.npep.2015.09.008

Reyes, T. M., Lewis, K., Perrin, M. H., Kunitake, K. S., Vaughan, J., Arias, C. A., et al. (2001). Urocortin II: a member of the corticotropin-releasing factor (CRF) neuropeptide family that is selectively bound by type 2 CRF receptors. Proc. Natl. Acad. Sci. U.S.A. 98, 2843-2848. doi: 10.1073/pnas.051626398

Richardson, U. I. (1983). ACTH secretion in mouse pituitary tumor cells in culture: inhibition of CRF-stimulated hormone release by somatostatin. Life Sci. 33, 1981-1988. doi: 10.1016/0024-3205(83)90736-1

Rivier, J. E., and Rivier, C. L. (2014). Corticotropin-releasing factor peptide antagonists: design, characterization and potential clinical relevance. Front. Neuroendocrinol. 35, 161-170. doi: 10.1016/j.yfrne.2013.10.006

Rocheville, M., Lange, D. C., Kumar, U., Sasi, R., Patel, R. C., and Patel, Y. C. (2000). Subtypes of the somatostatin receptor assemble as functional homoand heterodimers. J. Biol. Chem. 275, 7862-7869. doi: 10.1074/jbc.275.11.7862

Saffran, M., Schally, A. V., and Benfey, B. G. (1955). Stimulation of the release of corticotropin from the adenohypophysis by a neurohypophysial factor. Endocrinology 57, 439-444. doi: 10.1210/endo-57-4-439

Scheich, B., Gaszner, B., Kormos, V., Laszlo, K., Adori, C., Borbely, E., et al. (2016). Somatostatin receptor subtype 4 activation is involved in anxiety and depression-like behavior in mouse models. Neuropharmacology 101, 204-215. doi: 10.1016/j.neuropharm.2015.09.021

Schindler, M., and Humphrey, P. P. (1999). Differential distribution of somatostatin sst2 receptor splice variants in rat gastric mucosa. Cell Tissue Res. 297, 163-168. doi: 10.1007/s004410051344

Schulz, S., Handel, M., Schreff, M., Schmidt, H., and Hollt, V. (2000). Localization of five somatostatin receptors in the rat central nervous system using subtype-specific antibodies. J. Physiol. Paris 94, 259-264. doi: $10.1016 / S 0928-4257(00) 00212-6$
Sekino, A., Ohata, H., Mano-Otagiri, A., Arai, K., and Shibasaki, T. (2004). Both corticotropin-releasing factor receptor type 1 and type 2 are involved in stressinduced inhibition of food intake in rats. Psychopharmacology (Berl) 176, 30-38. doi: 10.1007/s00213-004-1863-1

Shibasaki, T., Kim, Y. S., Yamauchi, N., Masuda, A., Imaki, T., Hotta, M., et al. (1988a). Antagonistic effect of somatostatin on corticotropinreleasing factor-induced anorexia in the rat. Life Sci. 42, 329-334. doi: 10.1016/0024-3205(88)90642-X

Shibasaki, T., Yamauchi, N., Kato, Y., Masuda, A., Imaki, T., Hotta, M., et al. (1988b). Involvement of corticotropin-releasing factor in restraint stressinduced anorexia and reversion of the anorexia by somatostatin in the rat. Life Sci. 43, 1103-1110. doi: 10.1016/0024-3205(88)90468-7

Smith, S. M., and Vale, W. W. (2006). The role of the hypothalamic-pituitaryadrenal axis in neuroendocrine responses to stress. Dialogues Clin. Neurosci. $8,383-395$

Somiya, H., and Tonoue, T. (1984). Neuropeptides as central integrators of autonomic nerve activity: effects of TRH, SRIF, VIP and bombesin on gastric and adrenal nerves. Regul. Pept. 9, 47-52. doi: 10.1016/0167-0115(84) 90006-5

Spary, E. J., Maqbool, A., and Batten, T. F. (2008). Expression and localisation of somatostatin receptor subtypes sst1-sst5 in areas of the rat medulla oblongata involved in autonomic regulation. J. Chem. Neuroanat. 35, 49-66. doi: $10.1016 /$ j.jchemneu.2007.06.002

Steiger, A. (2007). Neurochemical regulation of sleep. J. Psychiatr. Res. 41, 537-552. doi: 10.1016/j.jpsychires.2006.04.007

Stengel, A., Coskun, T., Goebel, M., Wang, L., Craft, L., Alsina-Fernandez, J., et al. (2010). Central injection of the stable somatostatin analog ODT8-SST induces a somatostatin2 receptor-mediated orexigenic effect: role of neuropeptide $\mathrm{Y}$ and opioid signaling pathways in rats. Endocrinology 151, 4224-4235. doi: 10.1210/en.2010-0195

Stengel, A., Goebel-Stengel, M., Wang, L., Larauche, M., Rivier, J., and Taché, Y. (2011a). Central somatostatin receptor 1 activation reverses acute stress-related alterations of gastric and colonic motor function in mice. Neurogastroenterol. Motil. 23, e223-e236. doi: 10.1111/j.1365-2982.2011.01706.x

Stengel, A., Goebel-Stengel, M., Wang, L., Luckey, A., Hu, E., Rivier, J., et al. (2011b). Central administration of pan-somatostatin agonist ODT8-SST prevents abdominal surgery-induced inhibition of circulating ghrelin, food intake and gastric emptying in rats. Neurogastroenterol. Motil. 23, e294-e308. doi: 10.1111/j.1365-2982.2011.01721.x

Stengel, A., Karasawa, H., and Taché, Y. (2015). The role of brain somatostatin receptor 2 in the regulation of feeding and drinking behavior. Horm. Behav. 73, 15-22. doi: 10.1016/j.yhbeh.2015.05.009

Stengel, A., and Taché, Y. (2009). Neuroendocrine control of the gut during stress: corticotropin-releasing factor signaling pathways in the spotlight. Annu. Rev. Physiol. 71, 219-239. doi: 10.1146/annurev.physiol.010908.163221

Stengel, A., and Taché, Y. (2014a). Brain peptides and the modulation of postoperative gastric ileus. Curr. Opin. Pharmacol. 19, 31-37. doi: 10.1016/j.coph.2014.06.006

Stengel, A., and Taché, Y. (2014b). CRF and urocortin peptides as modulators of energy balance and feeding behavior during stress. Front. Neurosci. 8:52. doi: $10.3389 /$ fnins.2014.00052

Strowski, M. Z., Dashkevicz, M. P., Parmar, R. M., Wilkinson, H., Kohler, M., Schaeffer, J. M., et al. (2002). Somatostatin receptor subtypes 2 and 5 inhibit corticotropin-releasing hormone-stimulated adrenocorticotropin secretion from AtT-20 cells. Neuroendocrinology 75, 339-346. doi: 10.1159/0000 59430

Suda, T., Kageyama, K., Sakihara, S., and Nigawara, T. (2004). Physiological roles of urocortins, human homologues of fish urotensin I, and their receptors. Peptides 25, 1689-1701. doi: 10.1016/j.peptides.2004.03.027

Taché, Y. (2015). Corticotrophin-releasing factor 1 activation in the central amygdale and visceral hyperalgesia. Neurogastroenterol. Motil. 27, 1-6. doi: $10.1111 / \mathrm{nmo.} 12495$

Taché, Y., and Bonaz, B. (2007). Corticotropin-releasing factor receptors and stress-related alterations of gut motor function. J. Clin. Invest. 117, 33-40. doi: $10.1172 / \mathrm{JCI} 30085$

Taché, Y., Maeda-Hagiwara, M., and Turkelson, C. M. (1987). Central nervous system action of corticotropin-releasing factor to inhibit gastric emptying in rats. Am. J. Physiol. 253, G241-G245. 
Taché, Y., and Million, M. (2015). Role of corticotropin-releasing factor dignaling in dtress-related alterations of colonic motility and hyperalgesia. J. Neurogastroenterol. Motil. 21, 8-24. doi: 10.5056/jnm14162

Theodoropoulou, M., and Stalla, G. K. (2013). Somatostatin receptors: from signaling to clinical practice. Front. Neuroendocrinol. 34, 228-252. doi: 10.1016/j.yfrne.2013.07.005

Thoss, V. S., Perez, J., Duc, D., and Hoyer, D. (1995). Embryonic and postnatal mRNA distribution of five somatostatin receptor subtypes in the rat brain. Neuropharmacology 34, 1673-1688. doi: 10.1016/0028-3908(95)00135-2

Tizabi, Y., and Calogero, A. E. (1992). Effect of various neurotransmitters and neuropeptides on the release of corticotropin-releasing hormone from the rat cortex in vitro. Synapse 10, 341-348. doi: 10.1002/syn.890100409

Tringali, G., Greco, M. C., Lisi, L., Pozzoli, G., and Navarra, P. (2012). Cortistatin modulates the expression and release of corticotrophin releasing hormone in rat brain. Comparison with somatostatin and octreotide. Peptides 34, 353-359. doi: 10.1016/j.peptides.2012.02.004

Turnbull, A. V., and Rivier, C. (1997). Corticotropin-releasing factor (CRF) and endocrine responses to stress: CRF receptors, binding protein, and related peptides. Proc. Soc. Exp. Biol. Med. 215, 1-10. doi: 10.3181/00379727-215-44108

Vale, W., Spiess, J., Rivier, C., and Rivier, J. (1981). Characterization of a 41residue ovine hypothalamic peptide that stimulates secretion of corticotropin and beta-endorphin. Science 213, 1394-1397. doi: 10.1126/science.6267699

Van Pett, K., Viau, V., Bittencourt, J. C., Chan, R. K., Li, H. Y., Arias, C., et al. (2000). Distribution of mRNAs encoding CRF receptors in brain and pituitary of rat and mouse. J. Comp. Neurol. 428, 191-212.

Vaughan, J., Donaldson, C., Bittencourt, J., Perrin, M. H., Lewis, K., Sutton, S., et al. (1995). Urocortin, a mammalian neuropeptide related to fish urotensin I and to corticotropin-releasing factor. Nature 378, 287-292. doi: 10.1038/378287a0

Vecsei, L., and Widerlov, E. (1988). Effects of intracerebroventricularly administered somatostatin on passive avoidance, shuttle-box behaviour and open-field activity in rats. Neuropeptides 12, 237-242. doi: 10.1016/0143-4179(88)90061-3

Venihaki, M., Sakihara, S., Subramanian, S., Dikkes, P., Weninger, S. C., Liapakis, G., et al. (2004). Urocortin III, a brain neuropeptide of the corticotropin-releasing hormone family: modulation by stress and attenuation of some anxiety-like behaviours. J. Neuroendocrinol. 16, 411-422. doi: 10.1111/j.1365-2826.2004.01170.x

Videau, C., Hochgeschwender, U., Kreienkamp, H. J., Brennan, M. B., Viollet, C., Richter, D., et al. (2003). Characterisation of [125I]-Tyr0DTrp8-somatostatin binding in sst1- to sst4- and SRIF-gene-invalidated mouse brain. Naunyn Schmiedebergs Arch. Pharmacol. 367, 562-571. doi: 10.1007/s00210-003-0758-8

Viollet, C., Lepousez, G., Loudes, C., Videau, C., Simon, A., and Epelbaum, J. (2008). Somatostatinergic systems in brain: networks and functions. Mol. Cell. Endocrinol. 286, 75-87. doi: 10.1016/j.mce.2007.09.007

Viollet, C., Vaillend, C., Videau, C., Bluet-Pajot, M. T., Ungerer, A., L'heritier, A., et al. (2000). Involvement of sst2 somatostatin receptor in locomotor, exploratory activity and emotional reactivity in mice. Eur. J. Neurosci. 12, 3761-3770. doi: 10.1046/j.1460-9568.2000.00249.x
Wan, Q., Gao, K., Rong, H., Wu, M., Wang, H., Wang, X., et al. (2014). Histone modifications of the Crhrl gene in a rat model of depression following chronic stress. Behav. Brain Res. 271, 1-6. doi: 10.1016/j.bbr.2014. 05.031

Wang, L., Goebel-Stengel, M., Stengel, A., Wu, S. V., Ohning, G., and Taché, Y. (2011). Comparison of CRF-immunoreactive neurons distribution in mouse and rat brains and selective induction of Fos in rat hypothalamic CRF neurons by abdominal surgery. Brain Res. 1415, 34-46. doi: 10.1016/j.brainres.2011.07.024

Wu, S. V., Yuan, P. Q., Lai, J., Wong, K., Chen, M. C., Ohning, G. V., et al. (2011). Activation of Type $1 \mathrm{CRH}$ receptor isoforms induces serotonin release from human carcinoid BON-1N cells: an enterochromaffin cell model. Endocrinology 152, 126-137. doi: 10.1210/en.2010-0997

Wu, S. V., Yuan, P. Q., Wang, L., Peng, Y. L., Chen, C. Y., and Taché, Y. (2007). Identification and characterization of multiple corticotropin-releasing factor type 2 receptor isoforms in the rat esophagus. Endocrinology 148, 1675-1687. doi: 10.1210/en.2006-0565

Xu, M., Chung, S., Zhang, S., Zhong, P., Ma, C., Chang, W. C., et al. (2015). Basal forebrain circuit for sleep-wake control. Nat. Neurosci. 18, 1641-1647. doi: $10.1038 / \mathrm{nn} .4143$

Yang, L. Z., Tovote, P., Rayner, M., Kockskamper, J., Pieske, B., and Spiess, J. (2010). Corticotropin-releasing factor receptors and urocortins, links between the brain and the heart. Eur. J. Pharmacol. 632, 1-6. doi: 10.1016/j.ejphar.2010.01.027

Yuan, P. Q., Wu, S. V., Pothoulakis, C., and Taché, Y. (2016). Urocortins and CRF receptor type 2 variants in the male rat colon: gene expression and regulation by endotoxin and anti-inflammatory effect. Am. J. Physiol. Gastrointest. Liver Physiol. 310, G387-G398. doi: 10.1152/ajpgi.00337.2015

Yuan, P. Q., Wu, S. V., and Taché, Y. (2012). Urocortins and CRF type 2 receptor isoforms expression in the rat stomach are regulated by endotoxin: role in the modulation of delayed gastric emptying. Am. J. Physiol. Gastrointest. Liver Physiol. 303, G20-G31. doi: 10.1152/ajpgi.00547.2011

Zheng, J., Babygirija, R., Bulbul, M., Cerjak, D., Ludwig, K., and Takahashi, T. (2010). Hypothalamic oxytocin mediates adaptation mechanism against chronic stress in rats. Am. J. Physiol. Gastrointest. Liver Physiol. 299, G946G953. doi: 10.1152/ajpgi.00483.2009

Zmijewski, M. A., and Slominski, A. T. (2010). Emerging role of alternative splicing of CRF1 receptor in CRF signaling. Acta Biochim. Pol. 57, 1-13.

Conflict of Interest Statement: The authors declare that the research was conducted in the absence of any commercial or financial relationships that could be construed as a potential conflict of interest.

Copyright $\odot 2017$ Stengel and Taché. This is an open-access article distributed under the terms of the Creative Commons Attribution License (CC BY). The use, distribution or reproduction in other forums is permitted, provided the original author(s) or licensor are credited and that the original publication in this journal is cited, in accordance with accepted academic practice. No use, distribution or reproduction is permitted which does not comply with these terms. 